\title{
Trust or Usefulness? QR Code Payment Among Millennials in a Disrupted Market
}

\author{
Grace F. Djayapranata ${ }^{1, *} \&$ Andhy Setyawan ${ }^{2}$
}

\author{
${ }^{1}$ University of Surabaya, Surabaya, Indonesia \\ ${ }^{2}$ University of Surabaya, Surabaya, Indonesia \\ *Corresponding author. Email: gracedjayapranata@gmail.com
}

\begin{abstract}
The digitization trend has increased dramatically in the past decade. The development of the internet and the increasing use of smartphones worldwide indicate the starting of the industrial revolution 4.0, which is now moving into a society 5.0 era. This trend has affected almost all activities of human life, including marketing, where traditional transaction processes began to shift to the digital ones. Mobile payment using Quick Response (QR) code is one of the digital transaction options in Indonesia. This study aims to investigate the key factors that encourage millennials to use the QR code in the payment process. The study focuses on four variables: mobile usefulness, trust, attitude, and behavioral intention. Trust and usefulness are often the reasons people adopt new technologies, yet the question of which one is the most influential factor for millennials arises. To answer this question, researchers surveyed 165 Indonesian millennial respondents. The results show that usefulness has a direct positive effect on using QR codes in mobile payments. Meanwhile, trust has the largest indirect effect on using QR codes through the mediation of the attitude variable.
\end{abstract}

Keywords: QR Code, Mobile Payment, Usefulness, Trust, Behavioral Intention.

\section{INTRODUCTION}

The growth of smartphone users is rapidly increasing. In 2021, smartphone users exceed 5.22 billion people, with a growth rate of $1.8 \%$ or 93 million new users/year (Wardani, 2021). This is in line with the growth of internet users that is also increasing. These days, the growth of internet users reaches 4.66 billion with a growth rate of $7.3 \%$ (or 316 million people) compared to 2020. With this increasing trend, it is not surprising that digital transformation is also growing.

Moreover, the digitization trend is increasing along with the emergence of the Covid-19 pandemic. This pandemic is limiting human mobility so that all activities to fulfill their daily needs are done digitally. Almost every daily activity, such as buying vegetables, groceries, clothes, medicines, medical equipment, and so on, can be done online. This is in line with the McKinsey survey (2020) that reveals as many as $60 \%$ of global consumers have changed their spending patterns and prefer to stay at home (Charm et al., 2020). As many as $37 \%$ of consumers say that they will continue to make purchases through e-commerce. One of the implications of this change in consumer spending behavior is digital transactions. Digital transactions encourage people to adapt to payments using mobile payments/m-payment (De Luna et al., 2019). M-payment is a digital payment via smartphone. Digital payments (cashless) are 
increasing since the Covid-19 pandemic after March 2020 (Poon, 2020)

There are also more digital-based payment instruments, including Gopay, ShopeePay, OVO, AliPay, and others. Not to be left behind, even conventional banking players have entered m-payment market, for example, Mandiri E-money, BCA Sakuku, BRI Mobile, and so on. One of the objectives of m-payment is to provide effective and efficient services to the customers, and an option that providers can apply to provide effective and efficient services is by using QR Code.

In Indonesia, the use of $\mathrm{QR}$ codes in payments is a new thing. Although relatively new, QR codes are widely used by various $\mathrm{m}$ payment service providers, as evidenced by almost all $\mathrm{m}$-payment service providers have QR code-based technology. In addition, the Republic of Indonesia government also supports the use of QR code-based payment technology by issuing QRIS. QRIS is a national standardized QR code-based payment service that can be accessed using any $\mathrm{m}$ payment services. Marketing research on the adoption of m-payments has been widely carried out, but only few literatures discuss the adoption of $\mathrm{QR}$ code on payments. In addition, the $\mathrm{QR}$ code is one of the technologies that accelerates the payment process (Yan et al., 2021). Therefore, research on QR codes is important and interesting to reveal the various factors that drive the intention to adopt this technology. This research will discuss the key factors in the adoption process of using QR codes in $\mathrm{m}$ payments among millennials.

\subsection{Mobile Usefulness}

Mobile usefulness refers to the extent to which technology can generate significant value in improving individual performance in transactions (Ooi \& Tan 2016, Olaleye et al. 2018). Basically, people will use particular technology if they feel its benefits, such as speed, safety, and comfort. Specifically, the use of technology in this study is on the use of QR codes in m-payments. Before consumers adopt a technology (in this case, QR code), consumers will assess the perceived usefulness of other payment systems (Shankar \& Datta 2018), for example, by comparing cash with QR code payments. The results of this evaluation can be in the form of consumer attitudes. In line with this, Davis (1989) states that it is the main antecedent that affects attitudes in adapting technology. Several previous studies reveal that mobile usefulness affects consumer intentions and attitudes to adapt to the technology use (Ooi \& Tan 2016, Lew et al. 2020, Liébana-Cabanillas et al. 2020). Based on this description, the first and third hypotheses are proposed as follows.

H1: Mobile usefulness has a positive effect on behavioral intentions of using QR codes in $\mathrm{m}$ payments.

H3: Mobile usefulness has a positive effect on attitudes of using QR codes in m-payments.

\subsection{Trust}

Trust refers to the subjective belief that an object (in this case, m-payment service provider) has integrity and goodwill and competent to carry out its obligations to create a sense of security and comfort when using payment technology (Zhou 2013). Several studies reveal that trust is a major predictor of technology adoption behavior (Shao et al. 2019, Gong et al., 2020). In other words, without trust in service providers, consumers will not have a convincing experience when using payment technology. Furthermore, trust is also a key in determining future actions (Shin 2010, Srivastava et al. 2010). Trust in m-payment service providers can form a positive attitude. Research conducted by Sarkar et al. (2020) shows that trust in using a system also positively affects attitudes. Therefore, the proposed hypotheses are as follows.

$\mathrm{H} 2$ : Trust has a positive effect on behavioral intentions of using QR codes in m-payments. 
H4: Trust has a positive effect on attitude of using QR codes in m-payments.

\subsection{Attitude}

Attitude indicates the extent to which consumers have positive or negative evaluations of the behavior shown (Ajzen 1991). Referring to the Theory of Reasoned Action (TRA), a person's attitude positively affects his/her behavioral intentions (Fishbein \& Ajzen 1975). That is, if someone has a positive attitude, then that person tends to have a positive behavioral intention. Furthermore, this study examines the effects of consumer attitudes in using QR codes to adopt the technology. Several studies show that attitude has a positive effect on consumer intentions to adopt technology (Patil et al. 2020, Ho et al. 2020). Therefore, the fifth hypothesis is stated as follows.

H5: Attitude has a positive effect on behavioral intention of using QR code in $\mathrm{m}$ payment.

\section{RESEARCH METHODS}

This research used a survey to collect the data by distributing questionnaires. The survey was conducted using judgmental sampling, which was distributed to people with the following criteria: millennials who are at least 17 years old, have an m-payment account, and have used m-payment transactions using a $\mathrm{QR}$ code in the past six months.

This study has dependent and independent variables. The dependent variable is the behavioral intention, while the independent variables are mobile usefulness, trust, and attitude. All research variables were measured using a 5-point Likert scale ranging from 1 (strongly disagree) to 5 (strongly agree). The operational definition of the variable was adapted and modified from previous research. Items measuring mobile usefulness and behavioral intention were adapted from Yan et al. (2021). The trust variable was measured by adapting the research instrument of Patil et al. (2020), and the attitude variable was measured using the measurement adaptation of Schierz et al. (2010).

The research data of 165 respondents were analyzed using the Structural Equation Modeling (SEM) technique with the help of AMOS 23 software. The SEM approach was chosen because it provides a comprehensive estimate of the relationship between measurement items and the relationship between latent variables (Hair et al., 2019). The SEM modeling strategy follows Anderson \& Gerbing's (1988) suggestion, consisting of a measurement model and a structural model. The validity and reliability of the measurement model were tested, while the structural model was done to test the research hypotheses.

\section{RESULTS AND DISCUSSION}

Table 1 shows the results of validity and reliability testing. The Goodness of Fit (GOF) value in the measurement model shows good criteria $(\chi 2 / \mathrm{df}=1.548, \mathrm{RMSEA}=0.058, \mathrm{GFI}=$ 0.909, CFI $=0.964$, and TLI $=0.955)$. Referring to Hair et al. (2019), a good variable measuring item must meet the validity and reliability requirements. The validity of a measurement item is indicated by a standardized factor loading $(\lambda)$ value, or an average variance extracted (AVE) value of at least 0.5 and construct reliability (CR) value of at least 0.7 to indicate good reliability.

The validity and reliability testing results in Table 1 show that all variable measurement items are valid and reliable. The values of standardized loading, AVE, and reliability constructs meet good validity and reliability requirements.

Next, the structural model is done for testing the research hypothesis. The structural GOF model meets the good fit criteria $\left(\chi^{2} / \mathrm{df}\right.$ 
$=1.548, \mathrm{RMSEA}=0.058, \mathrm{GFI}=0.909, \mathrm{CFI}=$ 0.964 , and TLI $=0.955$ ).

Table 1. Validity and Reliability on CFA Model

\begin{tabular}{lccl}
\hline Variables & $\begin{array}{l}\text { Std. loading } \\
(\lambda)\end{array}$ & AVE & CR \\
\hline \multicolumn{4}{l}{ Mobile Usefulness (MU) } \\
MU1 & 0.713 & & \\
MU2 & 0.656 & 0.501 & 0.800 \\
MU3 & 0.786 & & \\
MU4 & 0.668 & & \\
Trust (TR) & & & \\
TR1 & 0.771 & 0.726 & 0.888 \\
TR2 & 0.886 & & \\
TR3 & 0.893 & & \\
Attitude (ATT) & & \\
ATT1 & 0.831 & & \\
ATT2 & 0.746 & 0.580 & 0.846 \\
ATT3 & 0.736 & & \\
ATT4 & 0.729 & & \\
Behavioral intention (BI) & & \\
BI1 & 0.725 & & \\
BI2 & 0.728 & 0.462 & 0.774 \\
BI3 & 0.632 & & \\
BI4 & 0.627 & & \\
\hline
\end{tabular}

Referring to the structural model hypothesis testing shown in Figure 1 and Table 2, the direct effect of trust (H2) on behavioral intention is not supported. The influence of trust on behavioral intention is indirectly through the attitude path.

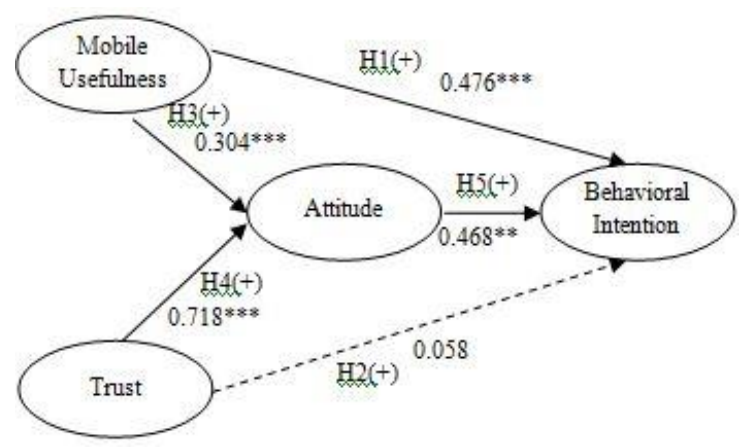

Figure 1. Structural Model Results

$* * p \leq 0.05$, *** $p \leq 0.001$.

The figure shows the standardized estimate value.

The dotted line indicates an insignificant path.
In contrast, to trust, the positive influence of mobile users on behavioral intention to use QR code in m-payment directly $(\beta=0.476, p$ $\leq 0.001)$ shows that empirical data support H1. Mobile usefulness $(\beta=0.304, p \leq 0.001)$ and trust $(\beta=0.718, p \leq 0.001)$ positively affect attitude towards QR code adoption in m-payments so that $\mathrm{H} 3$ and $\mathrm{H} 4$ are supported.

Finally, the data analysis shows that the positive attitude of consumers towards the adoption of QR code in m-payment encourages an increase in behavioral intention using QR code $(\beta=0.468, p \leq 0.05)$, indicating that empirical data support $\mathrm{H} 5$.

\begin{tabular}{|c|c|c|c|c|}
\hline Variable's path & $\begin{array}{l}\text { Std. } \\
\text { estimate } \\
(\beta)\end{array}$ & $\begin{array}{l}\text { Critical } \\
\text { ratio } \\
\text { (C.R.) }\end{array}$ & $p$ & Remarks \\
\hline $\mathrm{MU} \rightarrow \mathrm{BI}$ & 0.476 & 3.829 & $* * *$ & H1 supported \\
\hline $\mathrm{TR} \rightarrow \mathrm{BI}$ & 0.058 & 0.306 & 0.760 & $\begin{array}{l}\text { H2 not } \\
\text { supported }\end{array}$ \\
\hline $\mathrm{MU} \rightarrow \mathrm{ATT}$ & 0.304 & 3.911 & $* * *$ & $\mathrm{H} 3$ supported \\
\hline $\mathrm{TR} \rightarrow \mathrm{ATT}$ & 0.718 & 8.075 & $* * *$ & H4 supported \\
\hline $\mathrm{ATT} \rightarrow \mathrm{BI}$ & 0.468 & 1.995 & 0.046 & H5 supported \\
\hline
\end{tabular}

$\mathrm{BI}=$ Behavioral Intention; $\mathrm{MU}=$ Mobile Usefulness; $\mathrm{TR}=$ Trust ATT $=$ Attitude. $* * * p \leq 0.001$.

\section{CONCLUSION}

This study aims to investigate the behavioral intentions of $\mathrm{QR}$ code adoption in $\mathrm{m}$ payments among Indonesian millennials. Intention to use QR code is positively influenced by mobile usefulness and attitudes of millennial consumers. Usefulness is the main consideration for millennials to adopt QR codes, seen from its greater influence than attitude - the value perceived by young consumers. Attitude towards QR code adoption is built through trust and mobile benefits. The indirect effect of trust on intention to adopt QR codes through attitude is greater than the indirect effect of mobile usefulness. The higher the millennial trust in the QR code payment system, the more positive the attitude is formed, which 
encourages behavioral intentions to use $\mathrm{QR}$ codes in m-payments.

Broadly speaking, the key factors driving the intention to use QR code technology in mpayment are high usability, attitude, and consumer trust. However, consumer trust cannot directly improve usage behavior. Morgan \& Hunt (1994) state that trust is limited when there is no willingness to give. Furthermore, the willingness to be an important part of trust is that if someone believes but is unwilling to take risks that cannot be said to be distrustful. Sincerity in the will can be seen from the attitude. This is in line with our research findings, which show that consumer trust in $\mathrm{QR}$ code technology can influence behavior towards QR code usage.

Practically, QR code payments are currently booming due to the Covid-19 pandemic situation. By using QR codes, it is hoped that it can reduce the growth rate of Covid-19 infection. QR codes can avoid long payment queues to increase users' effectiveness and efficiency. In addition, using a QR code can also avoid physical contact so that it is very safe and comfortable to use for payments.

Referring to the research results, mpayment service providers and retailers need to increase the adoption of $\mathrm{QR}$ code technology by increasing its usability; a practical example is providing a $\mathrm{QR}$ code for the goods being sold so that consumers can immediately make payments without queuing at the cashiers. With the increasing perceived benefits, this will increase the attitude and intention of consumers to use QR codes in completing payment transactions.

\section{REFERENCES}

Ajzen, I. 1991. The theory of planned behavior. Organizational Behavior and Human Decision Processes 50: 179-211.
Anderson, J.C. \& Gerbing, D.W. 1988. Structural equation modeling in practice: $\mathrm{A}$ review and recommended two-step approach. Psychological Bulletin 103(3): 411-423

Charm, T., Perrey, J., Poh, F. \& Ruwadi, B. 2020. Navigating shopper behaviors in the pandemic. Available at www.mckinsey.com/businessfunctions/marketing-andsales/solutions/periscope/our-insights/surveys/2020holiday-season-navigating-shopper-behaviors-inthe-pandemic.

Davis, F.D. 1989. Perceived usefulness, perceived ease of use, and user acceptance of information technology. MIS Quarterly 13(3): 319-340

De luna, I.R., Liébana-Cabanillas, F., SánchezFernández, J. \& Muñoz-Leiva, F. 2019. Mobile payment is not all the same: The adoption of mobile payment systems depending on the technology applied. Technological Forecasting and Social Change 146:931-944

Fishbein, M. \& Ajzen, I. (1975). Belief, Attitude, Intention, and Behavior: An Introduction to Theory and Research, Reading, MA: Addison-Wesley

Gong, X., Zhang, K.Z.K., Chen, C., Cheung, C.M.K. \& Lee, M.K.O. 2020. What drives trust transfer from web to mobile payment services? The dual effects of perceived entitativity. Journal of Information \& Management 57(7): 103250

Hair, J.F., Black, W.C., Babin, B.J. \& Anderson, R.E. 2019. Multivariate data analysis (8th ed.). Englewood Cliffs: Prentice-Hall.

Ho, J. C., Wu, C-G., Lee, C-S. \& Pham, T-T.T. 2020. Factors affecting the behavioral intention to adopt mobile banking: An international comparison. Journal of Technology in Society, 63: 101360.

Lew, S., Tan, G.W-H., Loh, S-M., Hew, J-J. \& Ooi, KB. 2020. The disruptive mobile wallet in the hospitality industry: An extended mobile technology acceptance model. Journal of Technology in Society, 63: 101430.

Liébana-Cabanillas. F., Japutra. A., Molinilo, A., Singh, N. \& Sinha, N. 2020. Assessment of mobile technology use in the emerging market: Analyzing intention to use m-payment services in India. Journal of Telecomuniation Policy 44(9): 102009.

Morgan, R.M \& Hunt, S.D. (1994). The CommitmentTrust Theory of Relationship Marketing. Journal of Marketing, 58(3): 20-38

Olaleye, S.A., Salo, J., Sanusi, I.T. \& Okunoye, A.O. 2018. Retailing mobile app usefulness: Customer perception of performance, trust and tension free. International Journal E-Service Mobile Application (IJESMA) 10(4): 1-17.

Ooi, K-B. \& Tan, G.W-H. 2016. Mobile technology acceptance model: An investigation using mobile 
users to explore smartphone credit card. Journal of Expert System with Application 59: 33 - 46.

Patil, P., Tamilmani, K., Rana, N.P. \& Raghavan, V. 2020. Understanding consumer adoption of mobile payment in India: Extending Meta-UTAUT model with personal innovativeness, anxiety, trust, and grievance redressal. International Journal of Information Management, 54: 102144.

Poon, L. 2020. Coronavirus hastens the rise of the cashless economy. Available at https://www.bloomberg.com/news/articles/2020-0714/the-costs-ofan-increasingly-cashless-economy.

Sarkar, S., Chauhan, S, \& Khare, A. 2020. A metaanalysis of antecedents and consequences of trust in mobile commerce. International Journal of Information Management, 50: 286-301.

Schierz, P.G., Schlike, O. \& Wirtz, B.W. 2010. Understanding consumer acceptance of mobile payment services: An empirical analysis. Electronic Commerce Research and Application, 9: 209-21

Shankar, A. \& Datta, B. 2018. Factors affecting mobile payment adoption intention: An Indian perspective. Global Business Review, 19(3): 72-89.

Shao, Z., Zhang, L., Xiaotong, L. \& Guo, Y. 2019. Antecedents of trust and continuance intention in mobile payment platforms: The moderating effect of gender. Electronic Commerce Research and Applications, 33:100823.

Shin, D-H. 2010. Modeling the interaction of users and mobile payment system: Conceptual framework. International Journal of Human Computer Interaction 26(10): 917-940.

Srivastava, S.C., Chandra, S., \& Theng, Y.L. 2010. Evaluating the role of trust in consumer adoption of mobile payment system: An empirical analysis. Communication of the association for information system 27(1): 561-588.

Wardani, A.S. 2021. Pengguna internet dunia tembus 4,66 Miliar, rata-rata online di smartphone. Available at www.liputan6.com/tekno/read/4469008/penggunainternet-dunia-tembus-466-miliar-rata-rata-onlinedi-smartphone.

Yan, L-Y., Tan, G.W-H., Loh, X-M., Hew, J-J. \& Ooi, K-B. 2021. QR code and mobile payment: The disruptive forces in retail. Journal of Retailing and Consumer Services, 58: 102300.

Zhou, T. 2013. An empirical examination of continuance intention of mobile payment services. Decision Support Systems, 54(2): 1085-1091. 